\title{
Air solar collectors in building use - A review
}

\author{
Andrei-Stelian Bejan ${ }^{1}$, Abdelouhab Labihi ${ }^{2}$, Cristiana Croitoru, ${ }^{1, *}$ and Tiberiu Catalina ${ }^{1}$ \\ ${ }^{1}$ Technical University of Civil Engineering Bucharest, Faculty of Building Services, 021414 Pache Protopopescu Blvd., Bucharest, \\ Romania \\ ${ }^{2}$ Faculty of Sciences and Techniques, Cadi Ayyad University, LP2M2E Laboratory, Marrakech, Morocco
}

\begin{abstract}
In the current energy and environmental context it is imperative to implement systems based on renewable energy sources in order to reduce energy consumptions worldwide. Solar collectors are studied by many years and many researchers are focusing their attention in order to increase their efficiency and cost-effectiveness. Water solar collectors are often implemented for domestic hot water, heating or industrial processes and already have a place on the market. A promising system which is not yet widely known is represented by air solar collectors that could represent an efficient way to use the solar energy with a lower investment cost, a system that can be used in order to preheat the fresh air required for heating, drying, or to maintain a minimum temperature during winter. This paper presents a comprehensive literature review on air solar collectors used mainly in buildings, acting as a solar wall. Air solar collectors are roughly classified into two types: glazed and opaque. The present study comprises the solar collector classification, applications and their main parameters with a special focus on opaque solar collectors.
\end{abstract}

\section{Introduction}

The renewable sources can provide low-cost energy consumption solutions when using passive systems. Among these renewable sources, the use of systems which are using solar energy is largely acknowledged, being easy to implement and efficient from the accessibility point of view in the zones with solar potential. Such systems can respond to the European Directives concerning energy performance of buildings [1] which impose significant reduction of the energy consumption. Generally, building sector consumes $35.3 \%$ from the total energy demand [2, 3]. In this context the use of renewable energies is an attractive solution for fulfilling the two requirements: indoor quality and energy efficiency. Solar systems integrated in the building can use inertial elements where the energy is stored, or the solar energy is used to heat the fluid: air or water. Thermal systems can be classified into four important categories: systems that use a massive wall to store heat (known as solar walls or Trombe walls depending on some characteristics), systems that use water to store the heat, systems that use eutectic materials (or phase changing materials) and solar collectors.

Thermal solar collectors are a cost-effective method of using the solar energy as a renewable source of energy. These solutions have been used and studied since earliest times and can be classified into solar collectors using water and solar collectors using air. Solar water collectors are a more often an option for domestic hot water preparation or for preheating the thermal agent required for heating. Solar thermal air collectors are used to preheat the fresh air required for heating, drying, or to maintain a minimum temperature during winter. Unlike water collectors, the air collectors have the advantage that there is no risk of freezing and also, these systems have a lower environmental impact [4]. According to Goyal et al. [5], solar thermal air collectors can provide a temperature of up to $65{ }^{\circ} \mathrm{C}$, indicating a real interest in building use. The survey of literature allows us to be aware of the huge possibilities of such devices in energy recovery from the Sun.

A Transpired Solar Collector (TSC) or air solar collector is made of metal cladding with perforations, installed at a certain distance from a building wall, thus creating a cavity through which the air is circulating. The metal cladding is heated by the solar radiation from the sun and ventilation fans create negative pressure in the cavity, extracting the solar heated air through the perforated panel. The air is generally taken off at the top of the wall (due to air temperature gradients in the cavity) ensuring that all of the produced solar heat is collected and then distributed in the building via the ventilation system. The heat transfer between the fluid and the metal is enhanced depending on the flow's characteristics and other external parameters. Studies such as the ones of Van Decker et al. [6], Gunnewieck et al. [7, 8] are very interesting, given the information regarding the direct possibilities of improvement of these perforations and since the form of the orifices can be an important factor. The literature indicates the interest in using such technologies and the implementation of a special geometry for the perforations would conduct to a heat

\footnotetext{
* Corresponding author: cristiana.croitoru@utcb.ro
} 
transfer increase, but no significant studies have been published [9].

\section{Classification}

Depending on the construction characteristics, solar collectors can be classified in several ways. According to Lai et al. [10] solar air collectors can be grouped into:

- Opaque solar collectors

- Transparent or glazed solar collectors.

Opaque solar collectors may be of several types: solar collectors in which the absorber is plane, solar collectors in which the absorber is corrugated, solar collectors where the absorber is perforated, or solar collectors in which the opaque absorber is protected by a layer of glass. Glazed solar collectors can also be divided into several categories [11], respectively the Trombe wall (absorbing element having the role of thermal mass), solar collectors with a plane absorber. Both types of collectors can contain several coils to increase heat transfer and both types of collectors can be with or without heat storage media (inertial materials).

In figure 1, Nkwetta et al. [12] propose a way of classifying solar collectors according to their heat storage capacity.

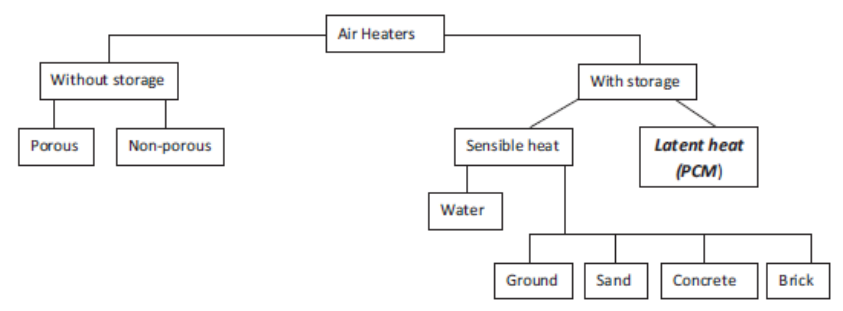

Fig. 1 Classification of solar thermal collectors according to the capacity to store the thermal energy according to [12]

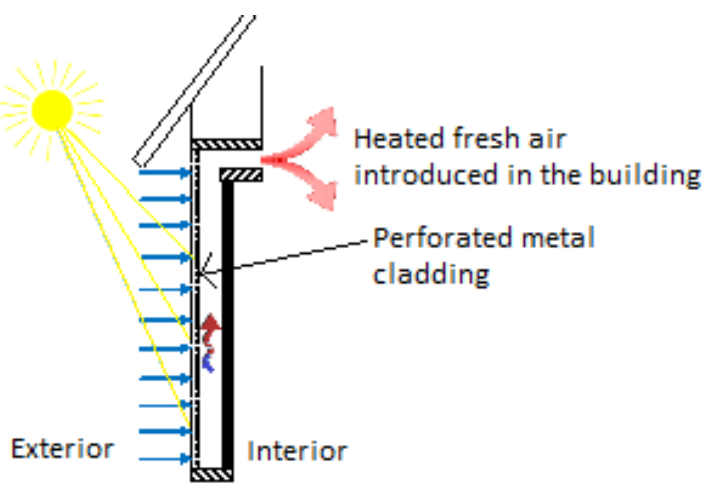

Fig. 2 Opaque solar thermal collector (perforated) model [13]

Regardless of their type, the functioning principle of the solar collectors is the same. Solar radiation is captured by an absorber that releases the heat to the circulating air through the formed cavity. In the case of an opaque solar collectors, the heat is usually captured by a dark metal panel or perforated panel (Figure 2), then it is ceded to the airflow which is then collected at the top of the collector and introduced into the room by a fan (in winter or during transition). If there are inertial elements integrated, the heat accumulated during the daytime can be later released at night. During daytime, in the summer season, the solar collector can function as a buffer space that reduces heat input through the building envelope or as a ventilated facade with the same role.

Regarding glazed solar collectors, the phenomenon is similar. Figure 3 represents a classic Trombe wall. The system is made up of a coating material (usually glass) that causes the greenhouse effect and allows the sun's radiation to penetrate (having the advantage of better lighting). Incidental solar radiation is captured by an absorbent layer with or without inertial elements, and then is released to the convective airflow. During the transition period and winter, the hot air can be used to heat the spaces or provide the fresh air needed. Accordingly to Hami et al. [11], Trombe walls and glazed solar collectors are the most used types of collectors.

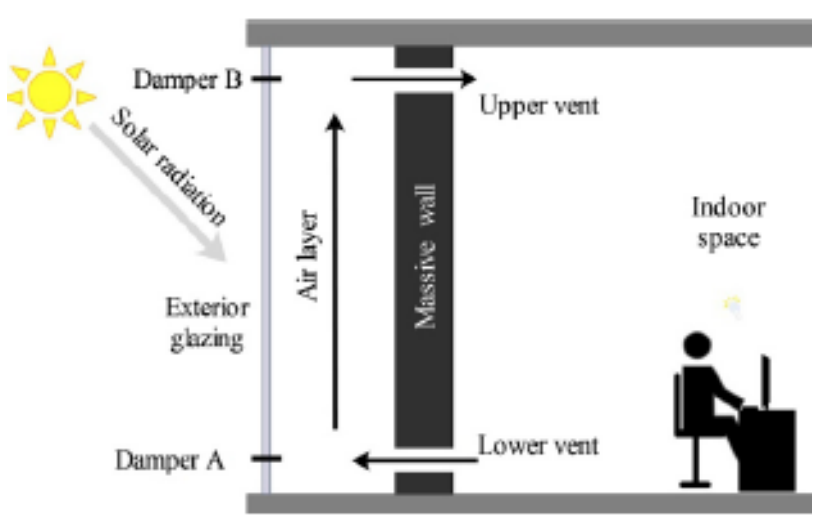

Fig. 3 Solar glazed solar collector model (Trombe wall) [14]

In figure 4, Shukla et al. [9] highlights the types of air solar collectors that have been studied so far (Figure 4). Figure 4a shows an opaque solar collector consisting of an absorbent element, the insulating wall and the cavity through which the air circulates. Figure $4 \mathrm{~b}$ shows a glazed solar collector consisting of a glass layer, the cavity through which the air circulates and an insulating wall on which the absorbent part is mounted. Figure $4 \mathrm{c}$ shows a collector similar to the previous, but with two glass sheets. Figure 4d shows an opaque solar collector in which the absorbent element is protected by a glass layer which releases the heat to the circulated air. In this case, the absorbent element can also be perforated (similar to Figure 4f). Figure 4e shows a multi-coil solar collector used to enhance thermal transfer, while Figure 4f shows an opaque solar collector in which the absorbent element is perforated and releases heat to the air penetrating into the cavity through the orifices. In each of the cases presented, the insulating wall may be replaced by a heat storage material (sensitive or latent).

Perforated opaque solar collectors typically have a lower implementation cost and higher efficiency when used in 
heating systems, fresh air preheating systems, or drying systems [15] and may also have lower lifetime costs [4]. Opaque solar collectors are typically used for applications where the required temperature is lower [16] and the side winds are not very strong [17].

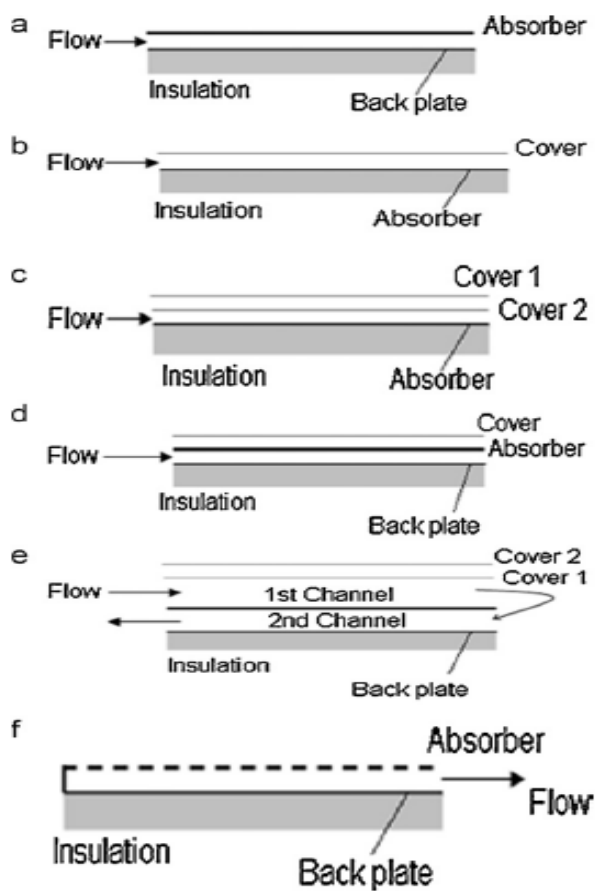

Fig. 4 Solar collector types [9]

According to different studies [12, 14, 15, 18-22], solar air collectors can be used for the following applications, with enormous potential to reduce energy consumption and operating costs [19]:

•buildings heating

- maintaining a low functioning temperature in industrial areas (for heating and drying of industrial halls)

- drying food

- preheating necessary fresh air

- heating and drying of greenhouses

-improving the efficiency of photovoltaic systems

- reducing energy consumption for cooling.

According to Leon and Kumar [19], solar air collectors have often been used for drying, using collectors with surfaces ranging from 90 to $1300 \mathrm{~m}^{2}$ which have provided an air temperature between $27-70^{\circ} \mathrm{C}$. In terms of building implementation, solar air collectors have been installed $[9,12,14,18]$ : in external walls (such as solar façades or ventilated facades), in the roof (as a ventilated roof) or as individual systems mounted on the roof, facade or exterior of the building. Another interesting solution involves the use of solar air for heating the air or other thermal agent for heat pumps [23, 24]. This way the performance coefficient of the air-towater heat pumps can be improved. Accordingly to Ciriminna et al. [21] the main obstacle to the implementation of solar collectors with air is low market reputation and difficult access to this type of technology.

\section{Applications}

Perforated opaque solar collectors are often used in buildings due to their low cost of implementation and efficiency [25]. They are already implemented in large buildings in Canada, US or Europe and have the potential to replace glazed solar collectors [19], the implementation degree having an upward trend [23]. Accordingly to Gunnewiek et al. [8] they are especially recommended when direct outdoor air heating is desired and can achieve efficiency up to $72 \%$.

Paya-Marin [26] has carried out an economic study on the implementation of opaque solar collectors. The author compared two types of opaque solar collectors, taking into account the installation and operating costs: collector without perforations (the air being oriented towards the back of the absorbent plate) and with a perforated collector. The payback period of the perforated collector is approximately 4 years, while in the case of the collector without perforations, the payback period is approximately 3 years (with an investment cost of $41 \%$ lower). However, the solar collector with perforations has a higher efficiency with $28 \%$, this aspect being underlined by Belusko et al. [27]. The presence of perforations within the absorber plate allows recovery of lost energy by convection and radiation at the surface of the plate [28, 29]. Accordingly to Chan et al. [29] the efficiency of the perforated opaque collectors is even $50 \%$ higher than the flat ones without perforations.

\section{Functioning parameters and energy efficiency of opaque solar collectors}

According to several studies [14, 25], the important parameters defining the operation of perforated opaque solar collectors are:

- the pitch between the perforations (and the porosity of the plate)

- the diameter of the perforations and the shape of the perforations

- plenum size (airflow cavity)

- absorption coefficient of the absorbent element

- ambient temperature

- air density

- kinematic viscosity

- thermal conductivity of the air

- solar radiation incident on the solar collector

- air flow and fan speed

- wind speed (lateral or front)

- the temperature of the absorbent plate

- the temperature of the exhaust air.

All these parameters are included in the calculation of the parameters that define the thermal performance of the collector, namely: the efficiency of the heat exchange $(\varepsilon \mathrm{HX})$, efficiency of the solar collector $(\eta)$ and temperature difference between the introduced air and the exhaust air $(\Delta \mathrm{T})$. 
Accordingly to Cirimina et al. [21] the most important parameter of an opaque solar collector with perforations is the heat exchange efficiency and its value depends on: the diameter and the pitch of the perforations, the thickness of the absorbent plate and the material from which it is made. The thermal efficiency of air solar collectors could be improved by using a series of baffles, obstacles or fins that increase the heat exchange surface and increase the uneven flow of the flow [27]. Goyal et al. [5] states that such a solution has a low investment cost and can increase collector efficiency by $10-15 \%$. A comprehensive bibliographic study on the types of absorbent elements that can be used to improve thermal transfer was performed by Razak et al. [30]. In general, the materials used to make the absorbing element are steel, copper, aluminium and plastic and its performance is influenced by porosity, geometry, thickness, heat exchange surface and material-specific properties.

The equations describing the energy balance and the characteristics of the perforated solar collectors are described by Leon and Kumar [19]. They also carried out a parametric study in which they assessed the influence of certain parameters on a perforated solar collector with the following characteristics: flow velocity $0.02-0.03 \mathrm{~m} / \mathrm{s}$, incident solar radiation $400-900 \mathrm{~W} / \mathrm{m}^{2}$, ambient temperature $30{ }^{\circ} \mathrm{C}$, wind velocity $1.2 \mathrm{~m} / \mathrm{s}$, pressure loss through the absorbent plate 25-80 $\mathrm{Pa}, 120$ $\mathrm{mm}$ cavity, $12-24 \mathrm{~mm}$ perforation pitch, $0.8-1.55 \mathrm{~mm}$ perforation diameter and a steel absorbent plate with an absorption coefficient of 0.95 and emissivity coefficient of 0.85 . According to the hypotheses taken into account, the absorbent plate and the opposite wall plate have the uniform (isothermal) temperature on the surface. The results found are interesting and can determine the choice of the type of solar collector:

- the temperature difference between the inlet and exhaust air decreases as the air flow increases, the pitch between the holes increases and the diameter of the holes increases

- the smaller the perforation diameter and the pitch between, the higher the heat exchange efficiency (but the pressure losses increase);

- the higher the solar radiation and the lower the air flow, the higher the air temperature

- the higher the absorption coefficient of the plate, the higher the resulting temperature (the emissivity coefficient has a lower impact).

Perforated opaque solar collectors have been used since the '90s to heat the air [14] and can lead to good performances [9]. An experimental study of Wang et al. [25] highlights the performance of an opaque solar collector with circular perforations. The collector walls are thermally insulated and there are no inertial elements embedded. The collector was positioned outdoor and subjected to external temperatures between $11-21^{\circ} \mathrm{C}$ and solar radiation values between $400-1000 \mathrm{~W} / \mathrm{m}^{2}$. Several plates with circular perforations with a diameter between $1 \mathrm{~mm}$ and $2 \mathrm{~mm}$ and a pitch of $20 \mathrm{~mm}$ to $30 \mathrm{~mm}$ were tested in the study. The airflow rates used were between
$80 \mathrm{~m}^{3} / \mathrm{h}$ and $200 \mathrm{~m}^{3} / \mathrm{h}$, and the resulting velocities were between $0.011 \mathrm{~m} / \mathrm{s}$ and $0.028 \mathrm{~m} / \mathrm{s}$. According to the study, the solar radiation should be higher than $400 \mathrm{~W} /$ $\mathrm{m}^{2}$ to reduce the radiant heat losses of the absorbing element to the exterior. The obtained results show a difference in temperature between the inlet and outlet air which varies between 10.55 and $31.16^{\circ} \mathrm{C}$ (the higher the air velocity, the lower the temperature achieved), a collector efficiency of 46.83-74.93\% (efficiency increases with increasing velocity), respectively a heat transfer efficiency between 61.99-82.32\% (which decreases with increasing velocity).

The ratio between the perforated collector height and its thickness should be less than $1 / 50$ [8]. According to [14, $19,21,31]$ the cavity through which the air circulates in the case of perforated collectors has a thickness of 5$30 \mathrm{~cm}$, the perforation surface varies between $0.5-2 \%$ of the total surface of the absorbent plate and it must not necessarily be of metal but may also be of plastics with low thermal conductivity [32]. However, the metal plates are isothermal in contrast to the rest of the materials, but this does not influence too much the performance of the collectors [19]. Vaziri et al. [33] have made a perforated collector in which they replaced the metal plate with plexiglass of $3 \mathrm{~mm}$ thick and have achieved superior efficiency when using plastic.

Plate emissivity is an important factor in influencing the efficiency of solar collectors. An extensive bibliographic study [34] on types of absorbent plates demonstrates that low emissivity can increase annual solar thermal output by up to $40 \%$. The same aspect is highlighted by Li et al. [35], the thermal transfer being more efficient when using an absorbent plate with a high absorption coefficient and low emissivity (the latter having a less significant impact).

A numerical study of Van Decker et al. [6] for a perforated opaque collector shows that about $62 \%$ of the thermal energy is released to the air in front of the absorbent plate, $28 \%$ in the orifice and about $10 \%$ behind the plate, and the thermal transfer efficiency decreases as the suction velocity, the pitch between the holes and the diameter of the holes increase and increases with increasing wind velocity and plate thickness.

Belusko et al. [27] has been studying the implementation of an opaque solar collector with a curved flat absorbent plate in the roof of a building. The air is aspirated at the bottom, recovers the heat from the corrugated board, and then it is introduced into the building. To improve heat transfer, the author proposes to make perforations in this plate, the air being entrained through the orifices even by the air driven behind the plate (creating a series of small jets). This process (also called "jet impingement") has improved the thermal efficiency of the solar collector by $21 \%$. If the diameter of the holes increases, the impact of this process decreases, and the thermal efficiency of the collector decreases from $69.3 \%$ to $66.4 \%$. Li et al. [36] proposes the use of flat opaque solar collectors, 
demonstrating that their efficiency is about $15 \%$ higher than that of corrugated opaque solar collectors.

Another study performed by Cordeau and Barrington [28] is showing the implementation of a perforated solar collector on a barn (see the principle in figure 5).
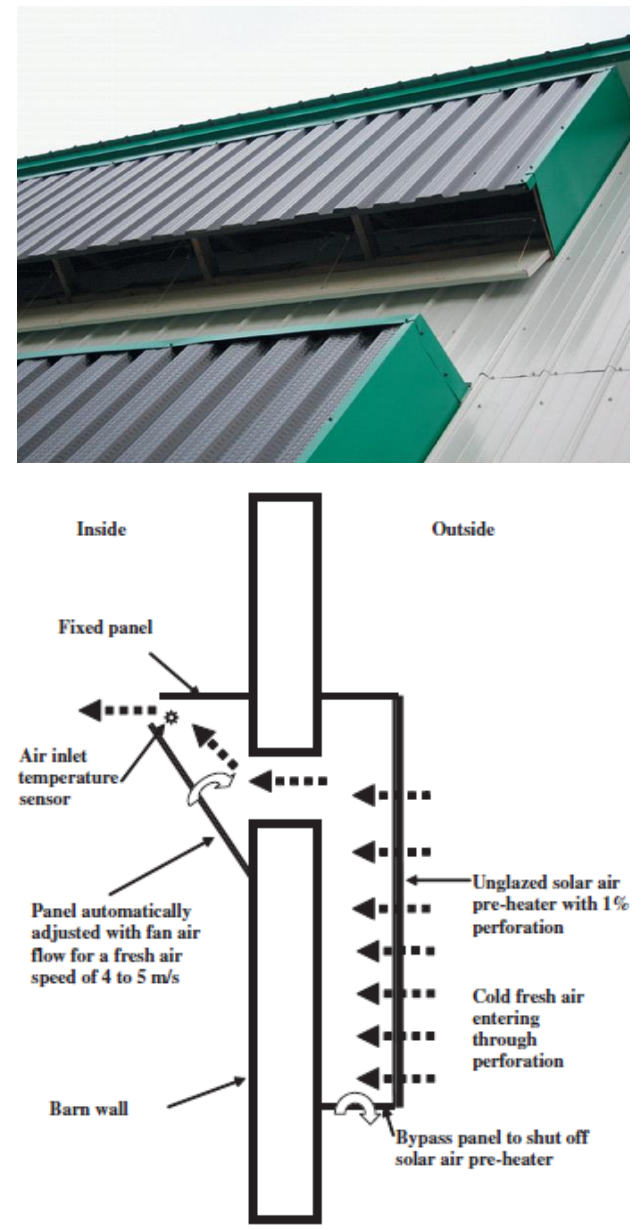

Fig. 5 Perforated solar collector in real conditions: photo and principle diagram [28]

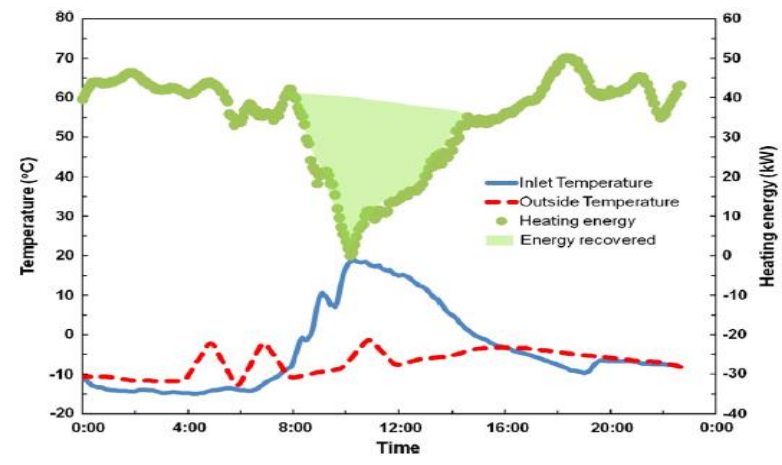

Fig. 6 Energy and temperature provided by a perforated opaque collector in real conditions (March 4, 2009) [28]

Figure 6 shows the results obtained during one day of operation. While the outdoor temperature varied between $-14{ }^{\circ} \mathrm{C}$ and $-1{ }^{\circ} \mathrm{C}$, the temperature of the air introduced by the solar collector reached $18{ }^{\circ} \mathrm{C}$ around 10:00 am and during the day, about 532MJ were saved for heating of the building $(147 \mathrm{kWh})$.

For less than $2 \mathrm{~m} / \mathrm{s}$ wind velocity, average efficiency was $65 \%$, and at high velocities (over $7 \mathrm{~m} / \mathrm{s}$ ), efficiency dropped below $25 \%$. Even under these conditions, the perforated solar collectors used in Cordeau and Barrington study have reduced the building's operating costs in the cold season by $\$ 14.8 / \mathrm{m}^{2}$.

The front or side wind significantly influence the efficiency of the solar air collectors accordingly to Gunnewiek et al. [8] and could reverse the flow direction (reverse flow effect), causing large pressure losses. According to the authors, the minimum suction velocity of the collector (airflow through the perforated plate relative to the total perforation surface), if there is no wind, it should be at least $0.0125 \mathrm{~m} / \mathrm{s}$. If the side wind has a velocity of $5 \mathrm{~m} / \mathrm{s}$, the minimum suction velocity should be greater than $0.017 \mathrm{~m} / \mathrm{s}$; if the wind blows on the front, the minimum suction velocity should be up to $0.039 \mathrm{~m} / \mathrm{s}$ if the angle of incidence is $45^{\circ}$. Collins and Abulkhair [37] have carried out experimental studies on a solar collector with perforations for wind velocities between $0.5-2 \mathrm{~m} / \mathrm{s}$ and perforation velocity between $0.01-0.04 \mathrm{~m} / \mathrm{s}$ and concluded that the efficiency of the heat exchange of the absorbent plate decreases with increasing suction velocity. To be able to carry out the numerical and experimental studies on solar collectors, Chan et al. [29] have made a number of assumptions: the radiant heat transfer to the surface of the plate is constant, convection losses to the environment are negligible, there is no inverse flow effect, and air properties at plenum flow are the same. Perforated solar collectors have better efficiency for uneven flows at low speeds [7].

Accordingly to Zhang et al. [14, 20], in the absence of wind, the perforated solar collector is more efficient with $13 \%$ resulting an air temperature increase of $3.4{ }^{\circ} \mathrm{C}$ in comparison with a perforated collector protected with a glass sheet (this reduces the effect of solar radiation) but at wind velocities greater than $3 \mathrm{~m} / \mathrm{s}$ the efficiency of the latter becomes superior. However, adding a glass sheet brings, besides the advantages mentioned, the benefit of better control (closure can be done through a flap) and a higher thermal insulation (thermal buffer).

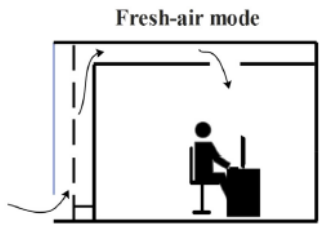

Mixture mode

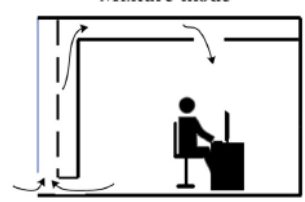

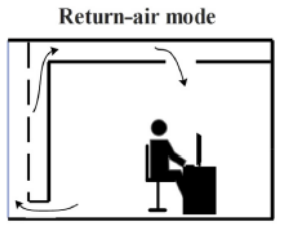

Off mode

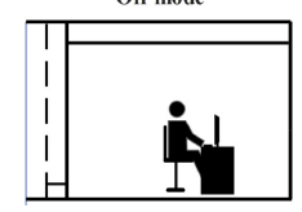

Fig. 7 Operating modes of a opaque solar collector with perforations protected with a glass sheet [20] 
The system is shown in figure 7, and the experimental results on a house in China show that indoor average temperature can be raised from $12.12{ }^{\circ} \mathrm{C}$ to $16.17-18.19$ ${ }^{\circ} \mathrm{C}$. An alternative to this solution that can be used for space heating is proposed by Zheng et al. [38] in a complex parametric study on a perforated solar collector protected with a glass layer closed at the bottom (the ventilated air is aspirated from inside, figure 8), and the temperature difference between the inlet air and the exhaust from the collector was up to $23^{\circ} \mathrm{C}$ in case of solar radiation of $1200 \mathrm{~W} / \mathrm{m}^{2}$.

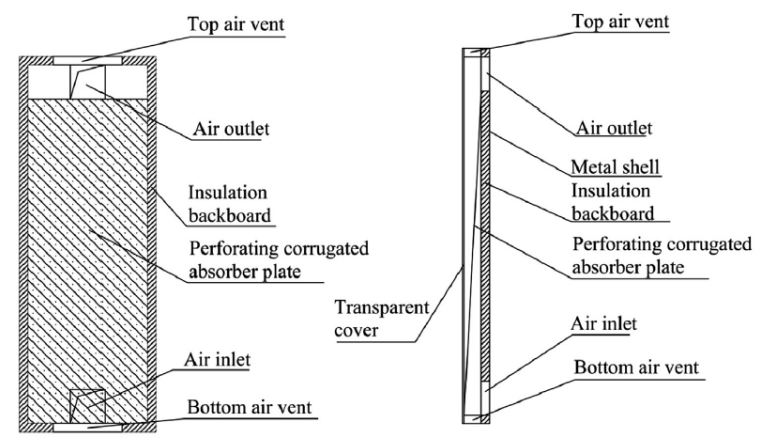

Fig. 8 Solar Collector perforated protected by a sheet of glass with no communication to exterior [38]

An opaque solar collector with high efficiency perforations was proposed by Croitoru et al. [13, 39]. The study proposes the use of lobed geometries instead of circular ones as perforations in classical solar collectors. Figure 9 shows the types of orifices studied. The lobed geometries used are $15 \%$ more efficient for flows between $80-220 \mathrm{~m}^{3} / \mathrm{h} / \mathrm{m}^{2}$ and can lead to an exhaust air temperature up to $2{ }^{\circ} \mathrm{C}$ higher. Unconventional lobed shape of the orifices causes a more complex flow which improves the heat transfer by $40 \%$ [13].
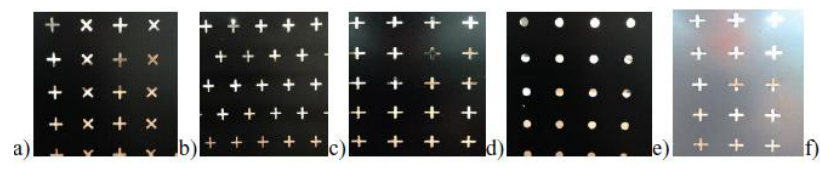

Fig. 9 Types of geometries for the orifices on the absorber [39]

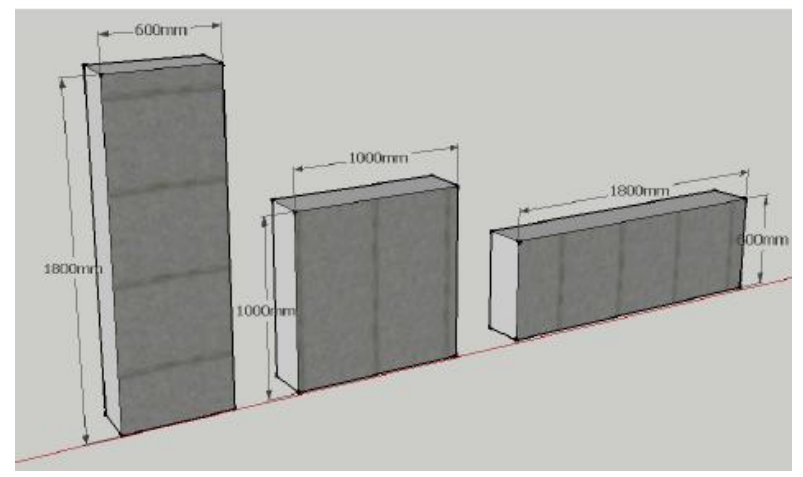

Fig. 10 Solar collectors with same area of $1 \mathrm{~m}^{2}$ [40]

An interesting study was conducted by Perisoglou and Dixon [40] which compared experimentally three solar collectors with a surface of $1 \mathrm{~m}^{2}$, but with different geometries (Figure 10). The study was conducted for an air duct velocity ranging from $1.5-5.5 \mathrm{~m} / \mathrm{s}$ and the results show efficiencies ranging between $19-71 \%$, respectively, temperature differences between inlet and outlet ranging from $5-22{ }^{\circ} \mathrm{C}$, while the collector placed horizontally had the highest efficiency. The authors also studied the position of the outlet in the collector and found that a $100 \mathrm{~mm}$ positioning from the top is better than a positioning in the middle of the collector (the air can pass through the absorbent plate).

Accordingly to Hollick [41] opaque perforated collectors combined with solar cells can be made. A classic collector can reduce annual energy consumption for heating with $500-1000 \mathrm{kWh} / \mathrm{m}^{2}$ of the collector, and combined with photovoltaic cells, it can produce around $50-100 \mathrm{kWh} / \mathrm{m}^{2}$ of electricity per year. In addition, the efficiency of the photovoltaic system may increase due to cell ventilation, and the efficiency of the collector may increase due to the heat from the photovoltaic cells.

Regarding the financial aspects, same author, Hollick, in another study [42] presents a commercially perforated solar collector which can determine a temperature difference between the inlet air and the outlet air of about $30-35 \%$ (the system is located at $25 \mathrm{~cm}$ from the building wall). Such a collector was implemented in a building covering a $335 \mathrm{~m}^{2}$ wall, covering $28 \%$ of the ventilation air demand $(195700 \mathrm{kWh})$, which translates into annual savings of $\$ 4860$ (for Canada's climate) and payback time of about 6 years. [43]. An interesting numerical and experimental study was conducted by Eryener and Akhan [44] on a $720 \mathrm{~m}^{2}$ air collector mounted in Turkey. The solar collector used supplies an air treatment system and has very good efficiency on sunny winter days, bringing down monthly costs by up to $62 \%$. Compared to classical heating solutions, perforated solar collectors have lower operating and running costs over their lifetime and the potential for reducing energy consumption for space heating in cold climates is very high [38].

\section{Conclusions}

Air solar collectors are widely studied and in the last years these technologies are gaining more and more attention from the researchers. This paper presents a literature review on air solar collectors acting as a solar wall with focus on transpired solar collectors. The existing applications are summarized and the performances and benefits are discussed. The study presents all the types of air solar collectors used and makes a classification based on the several applications found. Moreover, the main parameters of opaque solar collectors are presented and some particular cases are emphasized. From the literature survey we can observe that transpired solar collectors are cost-effective systems that could be used in order to gather energy from the Sun. Researchers are focusing their attention especially on the materials used, flows, collector geometry, dimensions and pitch of the orifices, but there are only a 
few studies regarding the impact of the orifices geometry. Also, we can observe a lack of studies about coupling the air solar collectors with thermal energy storage materials, which are used mainly in Trombe walls, but no study was found regarding the implementation of thermal energy storage (sensible or latent heat storage/phase changing materials) in transpired solar collectors. This strategy could enhance the overall efficiency of the collectors by lagging the thermal energy stored during the periods when solar radiation is available.

This work was supported by a grant of the Romanian National Authority for Scientific Research, CNCS - UEFISCDI, project number PN-III-P2-2.1-PED-2016-1154.

\section{References}

1. $\quad$ Energy, E.P.a.C.o., The Directive on the energy performance of buildings 2002/91/EC.

2. IEA, Renewables for heating and cooling: untapped potential. France: OECD/IEA; 2007.

3. Chan, H.-Y., S.B. Riffat, and J. Zhu, Review of passive solar heating and cooling technologies. Renewable and Sustainable Energy Reviews, 2010. 14(2): p. 781-789.

4. Reichl, C., et al., Comparison of modelled heat transfer and fluid dynamics of a flat plate solar air heating collector towards experimental data. Solar Energy, 2015. 120: p. 450-463.

5. Goyal, R.K., G.N. Tiwari, and H.P. Garg, Effect of thermal storage on the performance of an air collector: A periodic analysis. Energy Conversion and Management, 1998. 39(3): p. 193-202.

6. Van Decker, G.W.E., K.G.T. Hollands, and A.P. Brunger, Heat-exchange relations for unglazed transpired solar collectors with circular holes on a square or triangular pitch. Solar Energy, 2001. 71(1): p. 33-45.

7. Gunnewiek, L.H., E. Brundrett, and K.G.T. Hollands, Flow distribution in unglazed transpired plate solar air heaters of large area. Solar Energy, 1996. 58(4-6): p. 227-237.

8. Gunnewiek, L.H., K.G.T. Hollands, and E. Brundrett, Effect of wind on flow distribution in unglazed transpired-plate collectors. Solar Energy, 2002. 72(4): p. 317-325.

9. Shukla, A., et al., A state of art review on the performance of transpired solar collector. Renewable and Sustainable Energy Reviews, 2012. 16(6): p. 3975-3985.

10. Lai, C.-M. and S. Hokoi, Solar façades: $A$ review. Building and Environment, 2015. 91: p. 152-165.

11. Hami, K., B. Draoui, and O. Hami, The thermal performances of a solar wall. Energy, 2012. 39(1): p. 11-16.

12. Nkwetta, D.N. and F. Haghighat, Thermal energy storage with phase change material $-A$ state-of-the art review. Sustainable Cities and Society, 2014. 10: p. 87-100.

13. Croitoru, C.V., et al., Thermodynamic investigation on an innovative unglazed transpired solar collector. Solar Energy, 2016. 131: p. 21-29.

14. Zhang, T., et al., The application of air layers in building envelopes: A review. Applied Energy, 2016. 165: p. 707-734.

15. Dymond, C. and C. Kutscher, Development of a flow distribution and design model for transpired solar collectors. Solar Energy, 1997. 60(5): p. 291-300.

16. Molineaux, B., B. Lachal, and O. Guisan, Thermal analysis of five unglazed solar collector systems for the heating of outdoor swimming pools. Solar Energy, 1994. 53(1): p. 27-32.

17. Gao, L., H. Bai, and S. Mao, Potential application of glazed transpired collectors to space heating in cold climates. Energy Conversion and Management, 2014. 77: p. 690699.

18. Alkilani, M.M., et al., Review of solar air collectors with thermal storage units. Renewable and Sustainable Energy Reviews, 2011. 15(3): p. 1476-1490.

19. Leon, M.A. and S. Kumar, Mathematical modeling and thermal performance analysis of unglazed transpired solar collectors. Solar Energy, 2007. 81(1): p. 62-75.

20. Zhang, T., et al., A glazed transpired solar wall system for improving indoor environment of rural buildings in northeast China. Building and Environment, 2016. 98: p. 158-179.

21. Rosaria Ciriminna, F.M., Mario Pecoraino, Mario Pagliaro, Solar Air Heating and Ventilation in Buildings: A Key Component in the Forthcoming Renewable Energy Mix. Energy Technology, 2017. 5: p. 1-9.

22. Paya-Marin, M.A., et al., Large scale test of a novel back-pass non-perforated unglazed solar air collector. Renewable Energy, 2015. 83: p. 871-880.

23. Brown, C., et al., Transpired Solar Collector Installations in Wales and England. Energy Procedia, 2014. 48: p. 18-27.

24. Januševičius, K., et al., Validation of Unglazed Transpired Solar Collector Assisted Air Source Heat Pump Simulation Model. Energy Procedia, 2016. 95: p. 167-174.

25. Wang, X., et al., A simplified method for evaluating thermal performance of unglazed transpired solar collectors under steady state. Applied Thermal Engineering, 2017. 117: p. 185-192.

26. Paya-Marin, M.A., Chapter 5 - Solar Air Collectors for Cost-Effective Energy-Efficient Retrofitting, in Cost-Effective Energy Efficient Building Retrofitting. 2017, Woodhead Publishing. p. 141-168. 
27. Belusko, M., W. Saman, and F. Bruno, Performance of jet impingement in unglazed air collectors. Solar Energy, 2008. 82(5): p. 389398.

28. Cordeau, S. and S. Barrington, Performance of unglazed solar ventilation air pre-heaters for broiler barns. Solar Energy, 2011. 85(7): p. 1418-1429.

29. Chan, H.-Y., et al., Thermal Analysis of Flat and Transpired Solar Facades. Energy Procedia, 2014. 48: p. 1345-1354.

30. Razak, A.A., et al., Review on matrix thermal absorber designs for solar air collector. Renewable and Sustainable Energy Reviews, 2016. 64: p. 682-693.

31. Chan, H.Y., J. Zhu, and S. Riffat, Heat Transfer Analysis of the Transpired Solar Facade. Energy Procedia, 2013. 42: p. 123-132.

32. Arulanandam, S.J., K.G.T. Hollands, and E. Brundrett, $A C F D$ heat transfer analysis of the transpired solar collector under no-wind conditions. Solar Energy, 1999. 67(1-3): p. 93100.

33. Vaziri, R., M. Ilkan, and F. Egelioglu, Experimental performance of perforated glazed solar air heaters and unglazed transpired solar air heater. Solar Energy, 2015. 119: p. 251-260.

34. Hall, R. and J. Blower, Low-emissivity Transpired Solar Collectors. Energy Procedia, 2016. 91: p. 56-63.

35. Li, X., C. Li, and B. Li, Net heat gain assessment on a glazed transpired solar air collector with slit-like perforations. Applied Thermal Engineering, 2016. 99: p. 1-10.

36. Li, S., et al., Airflow and thermal analysis of flat and corrugated unglazed transpired solar collectors. Solar Energy, 2013. 91: p. 297-315.

37. Collins, M.R. and H. Abulkhair, An evaluation of heat transfer and effectiveness for unglazed transpired solar air heaters. Solar Energy, 2014. 99: p. 231-245.

38. Zheng, W., et al., Thermal characteristics of a glazed transpired solar collector with perforating corrugated plate in cold regions. Energy, 2016. 109: p. 781-790.

39. Croitoru, C., et al., Thermal Evaluation of an Innovative Type of Unglazed Solar Collector for Air Preheating. Energy Procedia, 2016. 85: p. 149-155.

40. Perisoglou, E. and D. Dixon, Experimental Monitoring of Different Dimensions of Transpired Solar Collectors. Energy Procedia, 2015. 70: p. 111-120.

41. Hollick, J.C., Solar cogeneration panels. Renewable Energy, 1998. 15(1-4): p. 195-200.

42. Hollick, J.C., Unglazed solar wall air heaters. Renewable Energy, 1994. 5(1-4): p. 415-421.

43. Hollick, J.C., World's largest and tallest solar recladding. Renewable Energy, 1996. 9(1): p. 703-707.
44. Eryener, D. and H. Akhan, The Performance of First Transpired Solar Collector Installation in Turkey. Energy Procedia, 2016. 91: p. 442-449. 